\title{
Chemical Transformation of Abietic Acid to New Chiral Derivatives
}

\author{
Catarina dos Santos ${ }^{a}$, Julio Zukerman-Schpector ${ }^{b}$ and Paulo M. Imamura ${ }^{*, a}$ \\ ${ }^{a}$ Instituto de Química, Universidade Estadual de Campinas, CP 6154, 13084-971 Campinas - SP, Brazil \\ ${ }^{b}$ Departamento de Química, Universidade Federal de São Carlos, CP 676, 13565-905 São Carlos - SP, Brazil
}

\begin{abstract}
Neste trabalho descrevemos as reações de transformações químicas do anel C do ácido abiético (1a) com o objetivo de gerar novos síntons quirais. A partir do intermediário ceto-aldeído 9, obtido através da reação de ozonólise do abietato de metila (1b), foram sintetizados derivados bicíclicos tais como 14, 15 e 16 e um novo diterpeno tetracíclico 4. Foram também sintetizados, a partir 17, novos derivados contendo esqueleto abeo-abietano[6,6,5] tais como $\mathbf{1 9}$ e $\mathbf{2 0 .}$
\end{abstract}

Chemical transformations of the C-ring abietic acid (1a) for the preparation of some new chiral synthons are described. From the intermediate keto-aldehyde $\mathbf{9}$, readily available from $\mathbf{1 b}$ through the ozonide 2, the new tetracyclic diterpene $\mathbf{4}$ was synthesized. Additionally, from $\mathbf{1 3}$ and $\mathbf{1 7}$, previously prepared from 2 , the bicyclic compounds 14,15 and 16 and the derivatives containing the abeo-abietane[6,6,5] framework 19 and $\mathbf{2 0}$ were also synthesized.

Keywords: abietic acid, ozonization, chiral synthon, abeo-abietane derivatives

\section{Introduction}

Abietic acid (Figure 1, 1a) is a diterpene readily available from an oleoresin produced by Pinus elliottii ${ }^{1}$ that shows activity as a chemical defense against insect and pathogenic fungi and bacteria. ${ }^{2}$ This acid has been used widely as an enantiomerically pure starting material in organic synthesis. ${ }^{3}$ Examples are the syntheses of Ambrox $^{\circledR}$, warburganal ${ }^{4}$ and some other sesquiterpenes. ${ }^{5}$ In order to evaluate the biological activities of the compounds obtained by modifying the framework of methyl ester $\mathbf{1 b}$, we first synthesized the stable ozonide $\mathbf{2}$ that showed activity against some lines of non-small lung cell, melanoma and breast cancers. ${ }^{6}$ We have also shown that some Diels-Alder adducts of $\mathbf{1 b}$ presented activities against Staphylococcus aureus, Bacillus subtilis and Micrococcus luteus. ${ }^{7}$ Starting with 2 we recently completed the synthesis of $\mathbf{3},{ }^{8}$ an analogue of a new class of compound named oidiolactone. ${ }^{9}$ In this paper we describe the transformation of 9 into the new tetracyclic derivative $\mathbf{4}$ and into its known diastereoisomer $\mathbf{5},{ }^{3}$ the transformation of $\mathbf{1 3}$ into the bicyclic compounds $\mathbf{1 4}, \mathbf{1 5}$ and $\mathbf{1 6}$ and also transformation of $\mathbf{1 7}$ into the new

* e-mail: imam@iqm.unicamp.br

This paper is dedicated to Prof. Albert J. Kascheres on occasion of his $60^{\text {th }}$ birthday
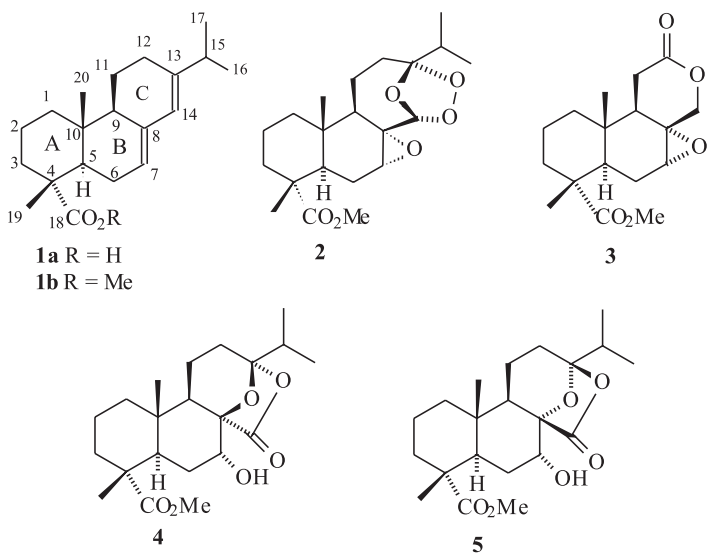

Figure 1. Structure of abietic acid (1a) and its derivatives $\mathbf{1 b}-\mathbf{5}$.

derivatives containing abeo-abietane[6,6,5] framework 19 and 20. Interestingly, compound $\mathbf{9 , 1 3}$ and $\mathbf{1 7}$ were all previously synthesized from ozonide $\mathbf{2} .{ }^{6,8}$

\section{Results and Discussion}

To explore a different reactivity of the double bonds in the $\mathrm{B}$ and $\mathrm{C}$-rings of $\mathbf{1 b}$, preliminary semi-empirical calculations (AM1 and PM3) were carried out using the SPARTAN ${ }^{\circledR 10}$ and Hyperchem ${ }^{\circledR}$ programs. ${ }^{11}$ The first analysis made was the Mulliken charges (Figure 2 - A and B) which showed the $\mathrm{C}$-ring to have a small, but higher, coefficient 
than the B-ring. On the other hand, HOMO coefficient calculations showed a slightly higher coefficient for C-7 than C-13 (Figure 2 - C).
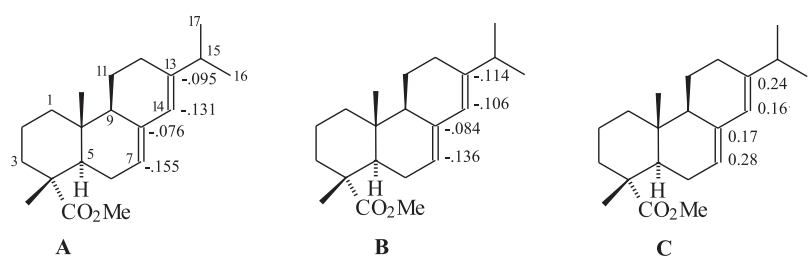

Figure 2. Results of Mulliken charges obtained by AM1 calculations (A left) and by PM3 calculations (B middle), and the HOMO coefficients ( $\mathrm{C}$ right).

These results led us to conclude that an electrophilic attack can occur either on the double bond at C-7 or at $\mathrm{C}-13$, and that the regioselectivity would depend on the reaction conditions and reactivity of the reagents. The literature gives examples where treatment of $\mathbf{1 b}$ with $\mathrm{OsO}_{4}^{4}$ or an epoxidation reaction with $m \mathrm{CPBA}^{12}$ occurred preferentially on the $\mathrm{C}$-ring. The oxidation of $\mathbf{1 b}$ with $\mathrm{I}_{2} / \mathrm{KHCO}_{3}$ at $50{ }^{\circ} \mathrm{C}\left(\mathrm{THF}: \mathrm{H}_{2} \mathrm{O} ; 47: 1\right)$ also occurred on the $\mathrm{C}$-ring and furnished the $\beta$-epoxide 6. However, when the reaction was carried out at $30{ }^{\circ} \mathrm{C}$, the $\mathrm{C}-7$ oxo-derivative $7^{13}$ (Figure 3) was obtained as the main product, showing that the reaction had occurred on the B-ring.

In a previous study we reported that the ozonolysis reaction of $\mathbf{1 b}$ in $\mathrm{CH}_{2} \mathrm{Cl}_{2}$ furnished compound $\mathbf{2}$, showing that the reaction took place at the $\mathrm{C}-7$ and $\mathrm{C}-13$ double bonds. ${ }^{6}$ Carrying out the reaction using $\mathrm{MeOH}-\mathrm{CH}_{2} \mathrm{Cl}_{2}$ $(1: 1)$ as solvent, we obtained compound $\mathbf{8}$ in $28 \%$ yield (Figure 3 ), in addition to a highly polar polymerized material. The formation of compound $\mathbf{8}$ showed that, under this condition, the electrophilic attack occurred at C-7 and $\mathrm{C}-13$ double bond of $\mathbf{1 b}$.
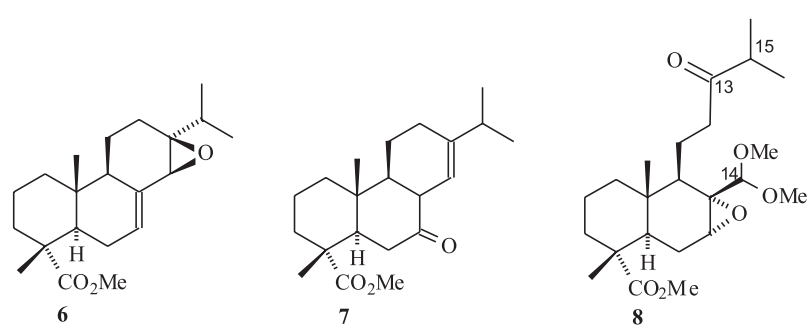

Figure 3. Structures of abietane derivatives 6-8.

Compound 8 was characterized by ${ }^{1} \mathrm{H}$ NMR spectral analysis where the signal at $\delta 4.08(\mathrm{~s}, 1 \mathrm{H})$ was assigned to $\mathrm{H}-14$ and the signals at $\delta 3.39,3.43$ and 3.64 were attributed to the methoxy groups of the acetal moiety and the methyl ester, respectively. The presence of an epoxy group at C-7 was observed in the ${ }^{1} \mathrm{H}$ NMR spectrum, through the signal of $\mathrm{H}-7$ at $\delta 3.21$, and was confirmed by ${ }^{13} \mathrm{C}$ NMR spectrum which showed signals of C-7 and C-8 at $\delta 54.6(\mathrm{CH})$ and at $\delta 59.8$ (C), respectively. The chemical shifts at $\delta 56.2$ and at $\delta 57.1$ confirmed the presence of the two methoxy groups of the acetal moiety at C-14 and the carbomethoxy group was observed at $\delta 52.0$. Two carbonyl carbons, one at $\delta 178.5$ assigned to the ester (C-18), and another at d 214.6, assigned to the ketone (C-13) were also observed. All other signals were in agreement with those observed for abietane models. $^{14}$

In an attempt to cleave the side chain of the bicyclic intermediate 9, ${ }^{6}$ we submitted it to a Baeyer-Villiger reaction induced by $m \mathrm{CPBA}$. Two compounds were isolated from the crude reaction product and were spectroscopically characterized as the tetracyclic compounds $4(50 \%)$ and $\mathbf{5}(33 \%)$, instead of the expected product $\mathbf{1 0}$ (Scheme 1).

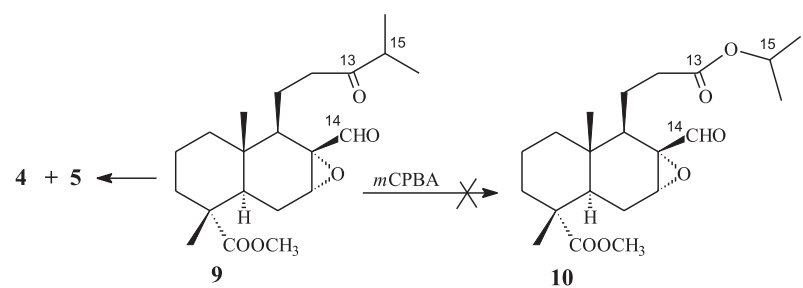

Scheme 1. Reaction of 9 with $m \mathrm{CPBA}$ to obtain $\mathbf{4}$ and $\mathbf{5}$.

The ${ }^{1} \mathrm{H}$ NMR spectrum of $\mathbf{4}$ showed a triplet at $\delta 3.93$ $(J 2.8 \mathrm{~Hz})$ assigned to $\mathrm{H}-7$, two multiplets at $\delta 1.79$ and $\delta 1.88$ assigned to $\mathrm{H}-12$ and two singlets at $\delta 1.10$ and $\delta 1.22$ assigned, respectively, to the methyl groups at $\mathrm{C}-20$ and $\mathrm{C}-19$. The ${ }^{13} \mathrm{C}$ NMR spectrum showed chemical shifts at $\delta 16.1$ and at $\delta 16.2$, which were assigned to the methyl groups at C-16 and C-17 and the signal at $\delta 114.1$ was assigned to the $\mathrm{C}-13$ of the ketal group. The chemical shift at $\delta 177.2$ was assigned to the carbonyl carbon of the lactone (C-14) and the presence of a carbonyl group was confirmed through the IR absorption at $1768 \mathrm{~cm}^{-1}$. All spectroscopic data were in good agreement with those reported for the model ambraketal analogues $\mathbf{1 1}$ and 12, previously synthesized by Scheidegger et al. ${ }^{15}$ (Figure 4) as well as for abietane model compounds. ${ }^{3,8}$ Compound 5 was also characterized by spectroscopic data analysis and through comparison with those reported previously by Haslinger $^{3}$ (Figure 4).

In view of these results we decided to study an alternative sequence, starting with $\mathbf{1 3},{ }^{6}$ to cleave its side chain. Our first choice was to analyze the preparation of intermediate 15 (Scheme 2).

The reduction of $\mathbf{1 3}$ with $\mathrm{NaBH}_{4} / \mathrm{MeOH}$ furnished, as expected, an inseparable mixture of epimeric alcohols 14 

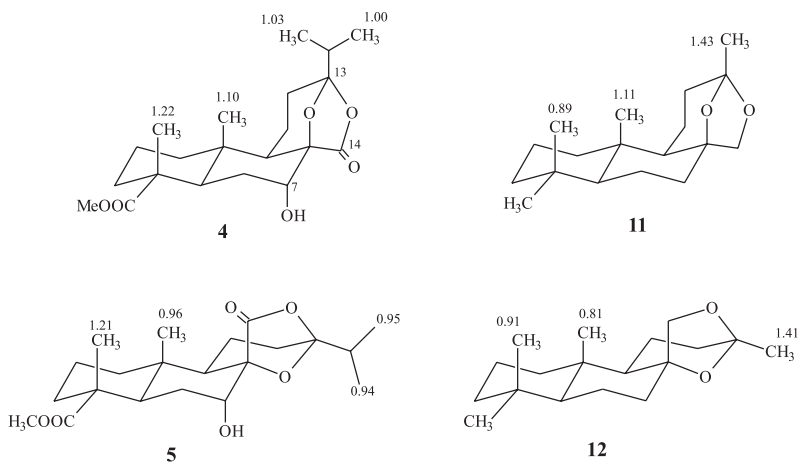

Figure 4. Structures of abietane derivatives $\mathbf{4}$ and $\mathbf{5}$ and ambraketal derivatives $\mathbf{1 1}$ and $\mathbf{1 2}$.

in $80 \%$ yield. The ${ }^{1} \mathrm{H}$ NMR spectrum of this mixture showed a multiplet at $\delta 3.34$, which was assigned to $\mathrm{H}-13$, and the ${ }^{13} \mathrm{C}$ NMR spectrum the signal at $\delta 76.6$ was also attributed to $\mathrm{C}-13$. Following the sequence, the dehydration reaction of 14 was carried out using $\mathrm{POCl}_{3}{ }^{16}$ where a mixture of olefins 15/16 (88:12) was obtained in 33\% yield. The best result was obtained when alcohol 14 was reacted with $\mathrm{MsCl}$, followed by treatment with $\mathrm{DBU}-\mathrm{Bz}^{17}$ to furnish a mixture of 15/16 (88:12) in 54\% yield.
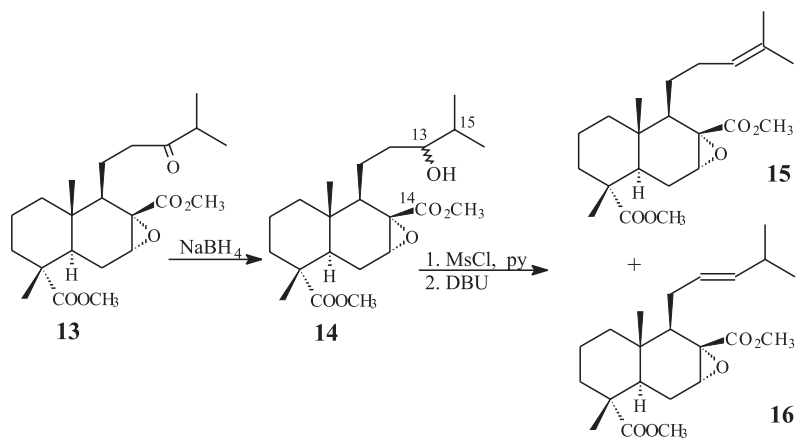

Scheme 2. Syntheses of $\mathbf{1 5}$ and $\mathbf{1 6}$ from $\mathbf{1 3 .}$

Compound 15 was characterized by ${ }^{1} \mathrm{H}$ NMR spectral analysis where a chemical shift of $\mathrm{H}-13$ as a broad triplet at $\delta 5.04(J 7.2 \mathrm{~Hz})$ and methyl groups of H-16 and H-17 attached to $\mathrm{sp}^{2}$ carbons at $\delta 1.60$ and at $\delta 1.69$ were observed. The ${ }^{13} \mathrm{C}$ NMR spectrum showed the signal of $\mathrm{C}-15$ at $\delta 132.2(\mathrm{C})$ and the signal of $\mathrm{C}-13$ at $\delta 125.2(\mathrm{CH})$ confirming the presence of the double bond. For compound 16, the chemical shift of $\mathrm{H}-12$ was observed at $\delta 5.25$ (ddd, $J 15.8 ; 7.2$ and $4.0 \mathrm{~Hz}$ ) and the chemical shift at $\delta 5.41(\mathrm{dd}$, $J 15.8$ and $6.0 \mathrm{~Hz}$ ) was assigned to $\mathrm{H}-13$. The chemical shift of $\mathrm{H}-15$ appeared at $\delta 2.22$ as a double septet and $\mathrm{H}-16$ and $\mathrm{H}-17$ appeared as a doublet at $\delta 0.94$. The presence of the double bond was also confirmed through ${ }^{13} \mathrm{C}$ NMR spectral analysis where the chemical shift of C-12 was observed at $\delta 123.7(\mathrm{CH})$ and the chemical shift of $\mathrm{C}-13$ was observed at $\delta 139.8$.

Since $\mathbf{1 3}$ is a highly oxygenated compound containing a very reactive oxirane ring and knowing that the transformation of the epoxide to the corresponding olefin is feasible, compound $\mathbf{1 3}$ was submitted to reaction with thiourea oxide ${ }^{18}$ and $\mathrm{PPh}_{3} / \mathrm{I}_{2} \cdot{ }^{19}$ In both cases only the starting material was recovered and attempts to open the epoxide to the corresponding diol using different conditions, such as $85 \% \mathrm{KOH} / \mathrm{DMSO},{ }^{20} \mathrm{H}_{2} \mathrm{SO}_{4} /$ acetone $^{21}$ or $\mathrm{KOH} / \mathrm{H}_{2} \mathrm{O}$ also failed. Further investigations on the bicyclic system to obtain potentially biologically active compounds such as anticancer, bactericidal and fungicidal compounds are now underway.

In order to obtain a more advanced chiral intermediate than the tricyclic compound $\mathbf{1 7}$, which was previously prepared in a reasonable yield $(45 \%, 2 \text { steps })^{8}$ from 2 , an oxidation reaction of the hydroxyl group at $\mathrm{C}-17$ was considered. Unfortunately, the oxidation reaction using different reagents, such as calcium hypochloride, ${ }^{22}$ Moffatt oxidation $^{23}$ and Jones reagent, ${ }^{23}$ led only to an intractable mixture of products or recovery of the starting material.

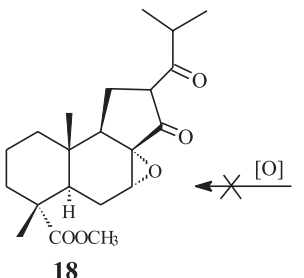

18

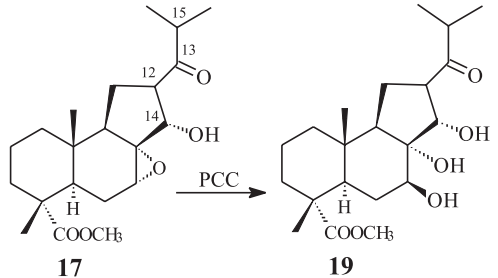

17
Scheme 3. Oxidation reaction of 17.

Surprisingly, treatment of $\mathbf{1 7}$ with $\mathrm{PCC}^{24}$ led to the triol 19 in $30 \%$ yield instead of to the expected oxidized product 18. This triol was characterized through ${ }^{1} \mathrm{H}$ NMR spectral analysis, where a signal at $\delta 4.35(\mathrm{dd}, J 12.0 \mathrm{~Hz}$ and $J 6.0 \mathrm{~Hz}$ ) assigned for $\mathrm{H}-7$, clearly deshielded when compared with H-7 of 17 (s, $\delta 3.27$ ), was observed, consistent with equatorial orientation of the hydroxyl group. All other signals, including $\mathrm{H}-12$ at $\delta 3.15$ (ddd, $J$ $13.5 ; 7.5$ and $5.2 \mathrm{~Hz}$ ), were in agreement with the structure depicted as 19. The HRMS data $\left(\mathbf{M}^{+}\right.$at $m / z$ 382.23553) also confirmed the molecular formula $\mathrm{C}_{23} \mathrm{H}_{34} \mathrm{O}_{6}$. The ${ }^{13} \mathrm{C}$ NMR spectrum showed the chemical shifts of C-7 and C-8 at $\delta 70.0(\mathrm{CH})$ and $81.0(\mathrm{C})$, respectively, and was consistent with the structure proposed as 19. The IR spectrum also showed three absorptions of hydroxyl group at 3546, 3515 and $3549 \mathrm{~cm}^{-1}$. Conversion of the epoxide to the diol in high selectivity, using chromium complexes like $[\mathrm{Cr}(\mathrm{N}$ $\left.\left.{ }^{\mathrm{t}} \mathrm{Bu}\right) \mathrm{Cl}_{3}(\mathrm{dme})\right]$ or $\left[\mathrm{V}(\mathrm{Ntol}) \mathrm{Cl}_{3}\right]$ (dme = 1,2-dimethoxyethane, tol $=p$-tolyl) is known in the literature and, 
according to Leung et al. ${ }^{25}$ formation of a five membered ring chelate seems to be more favorable than the six membered ring. ${ }^{25}$ Probably the chelation of the chromium ion with the oxygens of the epoxide and the hydroxyl group at C-12 from the $\alpha$ face, led to the attack of water from the $\beta$ face (at $\mathrm{C}-7$ ), to furnish the trans diol, as shown in Scheme 4.

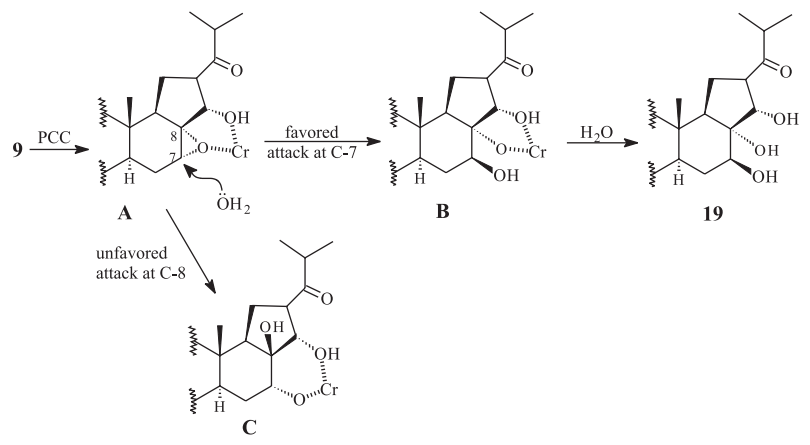

Scheme 4. Proposal of the mechanism for the synthesis of $\mathbf{1 9}$.

Due to the difficulties found in oxidizing compound 17, a Baeyer-Villiger reaction followed by oxidation and decarboxylation, in order to obtain $\mathbf{2 1}$, was considered. Following this sequence, treatment of $\mathbf{1 7}$ with $m \mathrm{CPBA}$ furnished 20 in $80 \%$ yield (Scheme 5).

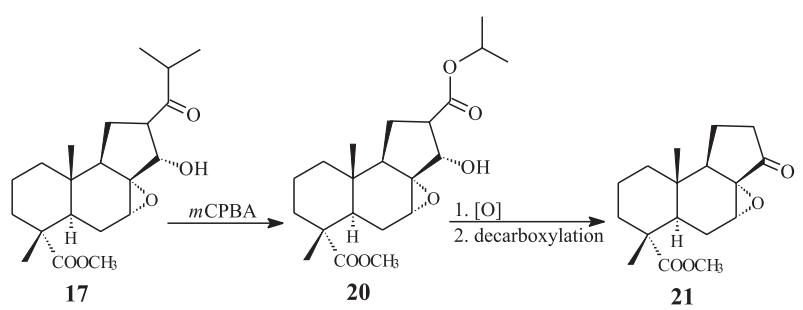

Scheme 5. Baeyer-Villiger oxidation of $\mathbf{1 7}$.

The ${ }^{1} \mathrm{H}$ NMR spectrum of $\mathbf{2 0}$ showed the chemical shift of methyl groups at $1.26(\mathrm{~d}, J 6.2 \mathrm{~Hz}, 3 \mathrm{H}, \mathrm{H}-16)$ and 1.28 (d, $J 6.2 \mathrm{~Hz}, 3 \mathrm{H}, \mathrm{H}-17$ ), slightly deshielded in comparison with those of $\mathbf{1 7}(\delta 1.13 ; \mathrm{d}, J 6.2 \mathrm{~Hz})$, as well as $\mathrm{H}-15$ which now appeared at $\delta 5.08$ (sept, $J 8 \mathrm{~Hz}$ ). The ${ }^{13} \mathrm{C} \mathrm{NMR}$ spectrum of $\mathbf{2 0}$ showed the chemical shift of methyl groups at $\delta 21.8(\mathrm{C}-16)$ and $\delta 21.9(\mathrm{C}-17)$ and a carbinolic carbon $\mathrm{C}-15$ at $\delta$ 68.2. The IR absorption at $1725 \mathrm{~cm}^{-1}$ and the ${ }^{13} \mathrm{C}$ NMR chemical shift at $\delta 173.4$ (C-13) confirm the presence of a carbonyl ester and the success of BaeyerVilliger oxidation reaction. Unfortunately, the oxidation reaction of the secondary alcohol of $\mathbf{2 0}$ using PCC or Jones reagent led only to recovery of the starting material.

None of the synthesized compounds presented significant activity against Artemia salina and any activities against $S$. aureus, B. subtilis and M. luteus. Further work is in progress in order to obtain a more elaborated tricyclic chiral synthon for the synthesis of drimane sesquiterpenes and biologically active compounds.

\section{Experimental}

NMR spectra were recorded on a Gemini 300P-Varian Instruments and Bruker AC $\left({ }^{1} \mathrm{H}\right.$ NMR at $300 \mathrm{MHz}$ and ${ }^{13} \mathrm{C}$ NMR at $75 \mathrm{MHz}$ ) or on a INOVA 500 - Varian Instruments $\left({ }^{1} \mathrm{H} \mathrm{NMR}\right.$ at $500 \mathrm{MHz}$ and ${ }^{13} \mathrm{C} \mathrm{NMR}$ at $125 \mathrm{MHz}$ ), in $\mathrm{CDCl}_{3}$ as solvent with TMS as internal standard. IR spectra were measured on a Perkin Elmer 1600 or on a BOMEM MB100 FTIR. Optical rotation was measured on a Carl Zeiss photoelectric polarimeter. High-resolution mass spectra (HRMS) were recorded with a VG 7070E spectrometer. For the HOMO/LUMO and Mulliken charge calculations, the programs PC SPARTAN ${ }^{\circledR}$ plus (version 1.5) and Hyperchem 6.03 professional $^{\circledR}$ were used. Column chromatography was performed by using Merck silica gel 60 (70-230 mesh) and TLC plates were performed using Merck $60 \mathrm{~F}_{254}$ silica gel on glass-supported plates.

\section{Synthesis of $\mathbf{8}$ from $\mathbf{1 b}$}

A stream of ozone was passed through a solution of $\mathbf{1 b}$ (238.0 mg, $0.78 \mathrm{mmol}$ ) in anhydrous $\mathrm{CH}_{2} \mathrm{Cl}_{2} / \mathrm{MeOH}(1: 1)$ (26.0 mL) at $-78{ }^{\circ} \mathrm{C}$ until a blue color persisted. Excess ozone was removed by passing nitrogen through the solution and the reaction mixture was treated with $\mathrm{PPh}_{3}$ (376.0 mg, $1.4 \mathrm{mmol}$ ). After stirring the mixture at room temperature for $8 \mathrm{~h}$, the solvent was removed in a rotary evaporator and the residue was chromatographed on silica gel ( $n$-hexane-EtOAc, $85: 15)$ to give $\mathbf{8}(87,8 \mathrm{mg}, 28 \%$ ) as a colorless oil: $[\alpha]_{\mathrm{D}}{ }^{20}+24.0\left(c 1.0, \mathrm{CHCl}_{3}\right)$; IR (film) $v_{\max } / \mathrm{cm}^{-1}: 2936,1725,1467,1387,1247,1083,755 ;{ }^{1} \mathrm{H}$ NMR (300 MHz) $\delta: 0.80$ (s, 3H, H-20), 0.98 (m, 1H, H-1), 1.12 (d, J 7.0 Hz, 6H, H-16, H-17), 1.19 (s, 3H, H-19), 1.38 (m, 1H, H-9), 1.50 (m, 2H, H-2), 1.53 (m, 2H, H-3), 1.65 (m, 1H, H-11), 1.72 (m, 2H, H-6), 1.80 (m, 1H, H-5), 1.82 (m, 1H, H-11'), 1.84 (m, 1H, H-1'), 2,51 (ddd, J 16.3, 10.0, 7.4 Hz, 1H, H-12), 2.62 (sept, J7.0 Hz, 1H, H-15), 2.76 (ddd, J 16.3, 10.0, 4.6 Hz, 1H, H-12' ), 3.22 (s, 1H, H-7), 3.39 (s, 3H, H-21), 3.43 (s, 3H, H-22), 3.64 (s, 3H, H-23), 4.08 (s, 1H, H-14); ${ }^{13} \mathrm{CNMR}$ (75 MHz) $\delta: 14.3$ (C-20), 17.1 (C-19), 17.4 (C-11), 18.1 (C-2), 18.2 (C-16), 18.3 (C-17), 24.0 (C-6), 35.6 (C-10), 36.9 (C-3), 37.7 (C-1), 40.8 (C-15), 41.0 (C-5), 42.6 (C-12, ) 46.6 (C-4), 52.0 (C-23), 54.6 (C-9), 54.6 (C-7), 56.2 (C-21), 57.1 (C -22), 59.8 (C-8), 106.7 (C-14), 178.5 (C-18), 214.6 (C-13); HRMS: Calcd for $\mathrm{C}_{23} \mathrm{H}_{38} \mathrm{O}_{6}$ : 410.26684; Found: $410.26295\left(\mathrm{M}^{+*}\right)$ 
Syntheses of $\mathbf{4}$ and $\mathbf{5}$ from $\mathbf{9}$

To a solution of $9(50.0 \mathrm{mg}, 0.27 \mathrm{mmol})$ in anhydrous $\mathrm{CH}_{2} \mathrm{Cl}_{2}(5.0 \mathrm{~mL})$ was added $99 \% \mathrm{mCPBA}(48.0 \mathrm{mg}, 0.54$ $\mathrm{mmol})$ and $\mathrm{NaHCO}_{3}(12.0 \mathrm{mg}, 0.27 \mathrm{mmol})$. The reaction mixture was kept in the dark with stirring at room temperature for 15 days. The mixture was filtered and the organic layer was washed with saturated $\mathrm{NaHCO}_{3}$ solution. The organic layer was dried over anhydrous $\mathrm{MgSO}_{4}$ and the solvent removed in a rotary evaporator. The residue was chromatographed on silica gel ( $n$-hexane- EtOAc, $85: 15)$ to furnish two products. Compound $4(25.5 \mathrm{mg}, 50 \%)$ was obtained as a colorless oil; $[\alpha]_{\mathrm{D}}{ }^{20}-11.5\left(c 1.5, \mathrm{CHCl}_{3}\right)$; IR (film) $v_{\max } / \mathrm{cm}^{-1}: 3511,2975,1768,1725,1389,1250,1162$, 1072, 737; ${ }^{1} \mathrm{H}$ NMR (300 MHz) $\delta: 0.94$ (m, 1H, H-1), 1.00 (d, J 7.0 Hz, 3H, H-16), 1.03 (d, J 7.0 Hz, 3H, H-17), 1.10 (s, $3 \mathrm{H}, \mathrm{H}-20$ ), 1.22 (s, 3H, H-19), 1.32 (ddd, J 14.4, 3.0, $2.2 \mathrm{~Hz}$, $1 \mathrm{H}, \mathrm{H}-6), 1.58(\mathrm{~m}, 1 \mathrm{H}, \mathrm{H}-3), 1.62(\mathrm{~m}, 2 \mathrm{H}, \mathrm{H}-2), 1.76(\mathrm{~m}, 1 \mathrm{H}$, H-6'), 1.78 (m, 1H, H-9), 1.79 (m, 1H, H-12), 1.80 (m, 1H, H-1'), 1.82 (m, 1H, H-3'), 1.88 (m, 1H, H-12'), 1.92 (m, 2H, H-11), 2.04 (sept, $J 6.8 \mathrm{~Hz}, 1 \mathrm{H}, \mathrm{H}-15$ ), 2.52 (dd, $J$ 13.0, 1.8 $\mathrm{Hz}, 1 \mathrm{H}, \mathrm{H}-5), 3.70$ (s, 3H, H-21), 3.93 (t, J $2.8 \mathrm{~Hz}, 1 \mathrm{H}, \mathrm{H}-7$ ), $4.07(\mathrm{~d}, J 2.2 \mathrm{~Hz}, \mathrm{OH}) ;{ }^{13} \mathrm{C}$ NMR $(75 \mathrm{MHz}) \delta: 16.1(\mathrm{C}-16)$, 16.2 (C-17), 16.5 (C-20), 16.6 (C-11), 16.9 (C-19), 17.6 (C-2), 25.8 (C-12), 27.5 (C-6), 34.5 (C-15), 36.6 (C-3), 38.5 (C-1), 38.5 (C-10), 40.1 (C-5), 41.0 (C-9), 47.1 (C-4), 52.2 (C-21), 68.5 (C-7), 80.7 (C-8), 114.7 (C-13), 177.2 (C-17), 178.9 (C-14); HRMS: Calcd for $\mathrm{C}_{21} \mathrm{H}_{32} \mathrm{O}_{6}: 380.21989$; Found: $380.21858\left(\mathrm{M}^{+}\right)$. Compound $\mathbf{5}(17.0 \mathrm{mg}, 33 \%)$ was obtained as colorless oil. All spectroscopic data were in a good agreement with those reported in the literature. ${ }^{3}$

\section{Synthesis of $\mathbf{1 4}$ from 13}

To a solution of $\mathbf{1 3}(79.3 \mathrm{mg}, 0.22 \mathrm{mmol})$ in anhydrous $\mathrm{MeOH}$ was added $\mathrm{NaBH}_{4}(10.0 \mathrm{mg}, 0.26 \mathrm{mmol})$. The mixture was stirred in an ice bath for $1 \mathrm{~h}$, then the solvent was evaporated and the residue was dissolved in EtOAc and washed with a saturated $\mathrm{NaCl}$ solution. The organic layer was dried over anhydrous $\mathrm{MgSO}_{4}$ and the solvent was removed in a rotary evaporator. The residue was chromatographed on silica gel ( $n$-hexane-EtOAc, 85:15) to give a mixture of epimeric alcohol $\mathbf{1 4}(60.8 \mathrm{mg}, 76 \%)$ as colorless oil. IR (film) $v_{\max } / \mathrm{cm}^{-1}: 3540,2954,2872,1728$, $1436,1389,1195,737 ;{ }^{1} \mathrm{H}$ NMR (300 MHz) $\delta: 0.88$ (d, $J$ $6.7 \mathrm{~Hz}, 3 \mathrm{H}, \mathrm{H}-16), 0.91$ (d, J $6.7 \mathrm{~Hz}, 3 \mathrm{H}, \mathrm{H}-17), 0.94$ (s, 3H, H-20), 1.04 (m, 1H, H-1), 1.22 (s, 3H, H-19), 1.29 (m, 1H, $\mathrm{H}-11), 1.38$ (m, 1H, H-9), 1.49 (m, 1H, H-14), 1.54 (m, 2H, $\mathrm{H}-2), 1.57$ (m, 1H, H-3), 1.61 (m, 2H, H-12), 1.64 (m, 1H, H-11'), 1.66 (m, 2H, H-6), 1.78 (m, 1H, H-3'), 1.82 (m, 1H, H-1'), 1.86 (m, 2H, H-5, -OH), 3.20 (t, J 2.6 Hz, 1H, H-7),
3.34 (m, 1H, H-13), 3.66 (s, 3H, H-21), 3.74 (s, 3H, H-22); ${ }^{13} \mathrm{C}$ NMR (75 MHz) $\delta: 14.7$ and 14.8 (C-20), $17.0(\mathrm{C}-19)$, 17.2 and 17.4 (C-16), 18.1 (C-2), 18.6 (C-17), 20.4 and 20.7 (C-11), 23.7 (C-6), 33.2 and 32.8 (C-12), 33.6 and 33.7 (C-15), 34.6 and 34.7 (C-10), 36.8 (C-3), 37.6 (C-1), 41.2 (C-5), 46.5 (C-4), 52.1 (C-21), 52.3 (C-22), 53.8 (C-9), 57.2 (C-7), 58.9 (C-8), 76.6 (C-13), 170.7 and 170.9 (C-14), 178.4 (C-18); HRMS: Calcd for $\mathrm{C}_{22} \mathrm{H}_{36} \mathrm{O}_{6}-\mathrm{H}_{2} \mathrm{O}$ : 378.24062; Found: $378.24059\left(\mathrm{M}^{+\bullet}-\mathrm{H}_{2} \mathrm{O}\right)$.

\section{Syntheses of 15 and 16 from 14}

$1^{\text {st }}$ method. To a solution of $\mathbf{1 4}(165.7 \mathrm{mg}, 0.42 \mathrm{mmol})$ in anhydrous $\mathrm{CH}_{2} \mathrm{Cl}_{2}(0.5 \mathrm{~mL})$, at $0{ }^{\circ} \mathrm{C}$, anhydrous pyridine ( $40 \mu \mathrm{L}, 0.96 \mathrm{mmol})$ and mesyl chloride $(75 \mu \mathrm{L}, 0.96 \mathrm{mmol})$ were added. After stirring for $1 \mathrm{~h}$, the ice bath was removed and reaction mixture was stirred at room temperature for another $8 \mathrm{~h}$. The mixture was diluted with EtOAc $(10.0 \mathrm{~mL})$ and washed successively with $5 \% \mathrm{HCl}$ and saturated solutions of $\mathrm{CuSO}_{4}$ and $\mathrm{NaHCO}_{3}$. The organic layer was dried over anhydrous $\mathrm{MgSO}_{4}$ and the solvent removed in a rotary evaporator. The residue was then dissolved in anhydrous benzene $(11.0 \mathrm{~mL})$ and DBU $(0.16 \mathrm{~mL}$, $1.1 \mathrm{mmol}$ ) was added. After refluxing for $48 \mathrm{~h}$, the reaction mixture was cooled to room temperature and the solvent was evaporated to the dryness. The crude product was dissolved in EtOAc $(20.0 \mathrm{~mL})$ and was washed with water. The organic layer was dried over anhydrous $\mathrm{MgSO}_{4}$ and the solvent was removed in a rotary evaporator. The residue was chromatographed on silica gel ( $n$-hexane-EtOAc, $85: 15)$ to furnish $\mathbf{1 5}$ and $\mathbf{1 6}(85.3 \mathrm{mg}, \mathbf{5 4 \%})$ in a ratio of $88: 12$, respectively.

$2^{\text {nd }}$ method. To a solution of $\mathbf{1 4}(73.0 \mathrm{mg}, 0.19 \mathrm{mmol})$ in anhydrous petroleum ether:pyridine $(1: 1,2.0 \mathrm{~mL})$ under nitrogen atmosphere, a solution of $\mathrm{POCl}_{3}(38 \mu \mathrm{l}, 0.40 \mathrm{mmol})$ in anhydrous petroleum ether $(1.0 \mathrm{~mL})$ was slowly added. After refluxing for $5 \mathrm{~h}$, the mixture was cooled to room temperature; water $(10.0 \mathrm{~mL})$ was added and the solution was extracted with EtOAc $(2 \times 10.0 \mathrm{~mL})$. The crude product was washed with water, dried over $\mathrm{MgSO}_{4}$ and the solvent was removed in a rotary evaporator. The residue was chromatographed on silica gel ( $n$-hexane-EtOAc, $85: 15)$ to furnish a mixture of $\mathbf{1 5}$ and $\mathbf{1 6}(23.0 \mathrm{mg}, 33 \%)$ as colorless oil in a ratio of $88: 12$, respectively. IR (film) $v_{\max } / \mathrm{cm}^{-1}$ : 2952, 1728, 1436, 1389, 1247, 737; For compound 15: ${ }^{1} \mathrm{H} N M R(500 \mathrm{MHz}) \delta: 0.92$ (s, 3H, H-18), 0.95 (m, 1H, H-1), 1.22 (s, 3H, H-19), 1.42-1,60 (m, 6H), 1.60 (s, 3H, H-16), 1.63-1.90 (m, 6H), 1.69 (s, 3H, H-17), 1.93 (m, 1H, H-11), 3.18 (m, 1H, H-7), 3,66 (s, 3H, H-21), 3.73 (s, 3H, H-22), 5.04 (bt, $J 7.2 ; 1.0 \mathrm{~Hz}, 1 \mathrm{H}, \mathrm{H}-13) ;{ }^{13} \mathrm{C}$ NMR $(125 \mathrm{MHz}) \delta: 14.8$ (C-20), 17.0 (C-19), 17.7 (C-2), 18.1 (C-16), 23.8 (C-6), 24.2 
(C-17), 25.7 (C-11), 27.0 (C-12), 34.6 (C-10), 36.7 (C-3), 37.6 (C-1), 41.2 (C-5), 46.4 (C-4), 52.0 (C-21), 52.1 (C-22), 53.5 (C-9), 57.2 (C-7), 58.8 (C-8), 125.2 (C-13), 132.2 (C-15), 170.6 (C-14), 176.2 (C-18); For compound 16: ${ }^{1} \mathrm{H}$ NMR (500 MHz) $\delta: 0.93$ (s, 3H, H-20), $0.94(\mathrm{~d}, J 6.0 \mathrm{~Hz}$, $6 \mathrm{H}, \mathrm{H}-16, \mathrm{H}-17) ; 0.95$ (m, 1H, H1), 1.22 (s, 3H, H-19), $1.421 .60(\mathrm{~m}, 4 \mathrm{H}), 1.63-1.90(\mathrm{~m}, 5 \mathrm{H}), 2.22$ (sept. $J 6.5 \mathrm{~Hz}$, $1 \mathrm{H}, \mathrm{H}-15$ ), 2.37 (dd, J 12.0, 7.2 Hz, 2H, H-11), 3.16 (m, 1H, H-7), 3.65 (s, 3H, H-21), 3.66 (s, 3H, H-22), 5.25 (ddd, J 15.8, 7.2, $4.0 \mathrm{~Hz}, 1 \mathrm{H}, \mathrm{H}-12$ ), 5.41 (dd. $J 15.8,6.0 \mathrm{~Hz}, 1 \mathrm{H}, \mathrm{H}-13$ ); ${ }^{13} \mathrm{C} \mathrm{NMR}(125 \mathrm{MHz}) \delta: 14.8$ (C-20), 17.0 (C-19), 17.7 (C-2), 22.3 (C-16), 22.4 (C-17), 23.7 (C-6), 23.8 (C-11), 31.2 (C-15), 34.6 (C-10), 36.7 (C-3), 37.6 (C-1), 41.2 (C-5), 46.4 (C-4), 52.0 (C-21), 52.1 (C-22), 53.5 (C-9), 57.2 (C-7), 58.9 (C-8), 123.7 (C-12), 139.8 (C-13), 170.6 (C-14), 178.2 (C-18); HRMS: Calcd. for $\mathrm{C}_{22} \mathrm{H}_{34} \mathrm{O}_{5}: 378.24062$; Found: $378.24157\left(\mathrm{M}^{+*}\right)$.

\section{Synthesis of 19 from 17}

To a solution of $\mathbf{1 7}(48.7 \mathrm{mg}, 0.13 \mathrm{mmol})$ dissolved in anhydrous $\mathrm{CH}_{2} \mathrm{Cl}_{2}(2.5 \mathrm{~mL})$, was added PCC $(57.7 \mathrm{mg}$, $0.26 \mathrm{mmol}$ ) at room temperature. After stirring for $8 \mathrm{~h}$, the reaction mixture was filtered through a small pad of silica gel and the solvent was removed in a rotary evaporator. The residue was chromatographed on silica gel $\left(\mathrm{CH}_{2} \mathrm{Cl}_{2}-\right.$ $\mathrm{MeOH}, 95: 5)$ to give $\mathbf{1 9}(16.0 \mathrm{mg}, 30 \%)$ as colorless crystals: $\mathrm{mp} 103-105{ }^{\circ} \mathrm{C} ;[\alpha]_{\mathrm{D}}{ }^{20}-85.0\left(c \mathrm{c} 1.8, \mathrm{CHCl}_{3}\right)$; IR (film) $v_{\text {max }} / \mathrm{cm}^{-1}: 546,3515,3459,2932,1716,1249,736$; ${ }^{1} \mathrm{H}$ NMR (300 MHz) $\delta: 0.73$ (s, 3H, H-20), 0.92 (m, 1H, H1), 1.10 (d, J6.8Hz, 3H, H-16), 1.12 (d, J6.8 Hz, 3H, H-17), 1.26 (s, 3H, H-19), 1.50 (m, 2H, H-2), 1.54 (m, 1H, H-6), 1.60 (m, 1H, H-1'), 1.62 (m, 2H, H-3), 1.70 (m, 1H, H-11), 1.88 (m, 1H, H-6'), 1.90 (m, 1H, H-5), 1.93 (sl, 1H, H-9), 2.35 (dt, J 3.5, 9.4 Hz, 1H, H-11), 2.65 (d, J $2.6 \mathrm{~Hz}, \mathrm{O} \underline{\mathrm{H}}$ at C-7) 2.87 (sept, $J 6.8 \mathrm{~Hz}, 1 \mathrm{H}, \mathrm{H}-15$ ), 3.15 (ddd, $J 13.5,7.5$, $5.2 \mathrm{~Hz}, 1 \mathrm{H}, \mathrm{H}-12$ ), 3.69 (s, 3H, H-21), 3.79 (s, OH at C-8), 4.35 (dd, $J 12.0,6.0 \mathrm{~Hz}, 1 \mathrm{H}, \mathrm{H}-7), 4.66$ (dd, $J 8.2,2.7 \mathrm{~Hz}$, $1 \mathrm{H}, \mathrm{H}-14), 5.1$ (m, O at C-14); ${ }^{13} \mathrm{C}$ NMR (75 MHz) $\delta: 15.8$ (C-20), 16.8 (C-19), 17.2 (C-2), 18.5 (C-16), 18.6 (C-17), 23.5 (C-11), 33.4(C-6), 36.5 (C-10), 36.6 (C-3), 39.0 (C-1), 39.1 (C-15), 46.7 (C-4), 47.1 (C-5), 52.2 (C-21), 53.9 (C-12), 60.0 (C-9), 70.0 (C-7), 75.5 (C-14), 81.0 (C-8), 178.4 (C-18), 214.0 (C-13); HRMS: Calcd for $\mathrm{C}_{21} \mathrm{H}_{34} \mathrm{O}_{6}$ : 382.23554; Found: $382.23553\left(\mathrm{M}^{+*}\right)$.

\section{Synthesis of $\mathbf{2 0}$ from $\mathbf{1 7}$}

To a solution of $\mathbf{1 7}(200.0 \mathrm{mg}, 0.56 \mathrm{mmol})$ in anhydrous $\mathrm{CH}_{2} \mathrm{Cl}_{2}(15.0 \mathrm{~mL})$ was added $99 \% \mathrm{mCPBA}$ (192.0 mg, 1.12 $\mathrm{mmol})$ and $\mathrm{NaHCO}_{3}(48.0 \mathrm{mg}, 0.56 \mathrm{mmol})$, and mixture was refluxed for 3 days. An additional portion of $99 \%$ $m$ CPBA $(96.0 \mathrm{mg}, 0.56 \mathrm{mmol})$ and $\mathrm{NaHCO}_{3}(24.0 \mathrm{mg}$, $0.28 \mathrm{mmol}$ ) were added, and the mixture was refluxed for another 3 days. The reaction mixture was filtered and the organic phase washed with a saturated $\mathrm{NaHCO}_{3}$ solution. The organic layer was dried over anhydrous $\mathrm{MgSO}_{4}$ and the solvent was removed in a rotary evaporator. The residue was chromatographed on silica gel $\left(\mathrm{CH}_{2} \mathrm{Cl}_{2}-\mathrm{MeOH}, 99: 1\right)$ to give 20 (167.5 mg, 80\%) as colorless crystals: $\mathrm{mp} 60$ $-62{ }^{\circ} \mathrm{C} ;[\alpha]_{\mathrm{D}}{ }^{20}-9.3\left(c 1.1, \mathrm{CHCl}_{3}\right)$; IR (film) $v_{\max } / \mathrm{cm}^{-1}: 3483$, 2985, 1725, 1459, 1252, 1106, 736; ${ }^{1} \mathrm{H}$ NMR (300 MHz) $\delta: 0.86$ (s, 3H, H-20), 1.19 (m, 1H, H-1), 1.25 (s, 3H, H-19), 1.26 (d, J 6.2 Hz, 3H, H-16), 1.28 (d, J $6.2 \mathrm{~Hz}, 3 \mathrm{H}, \mathrm{H}-17$ ), 1.48 (m, 1H, H-11), 1.52 (m, 2H, H-2), 1.60 (m, 1H, H-1'), 1.64 (m, 2H, H-3), 1.73 (dd, J 4.5, 1.8 Hz, 2H, H-6), 1.85 (m, $1 \mathrm{H}, \mathrm{H}-9), 1.88$ (m, 1H, H-5), 2.00 (ddd, J 12.7, 8.2, $6.2 \mathrm{~Hz}$, $\left.1 \mathrm{H}, \mathrm{H}-11^{\prime}\right), 2.30$ (d, J 7.7 Hz, O프), 2.60 (dq, J 9.6, $6.2 \mathrm{~Hz}$, 1H, H-12), 3.28 (s, 1H, H-7), 3.67 (s, 3H, H-21), 4.10 (dd, $J$ 10.0; $7.7 \mathrm{~Hz}, 1 \mathrm{H}, \mathrm{H}-14$ ), 5.08 (sept, $J$ 6.8, 1H, H-15); ${ }^{13} \mathrm{C}$ NMR (75 MHz) $\delta: 15.6$ (C-20), 17.4 (C-19), $17.6(\mathrm{C}-2)$, 21.8 (C-16), 21.9 (C-17), 24.3 (C-11), 24.4 (C-6), 33.5 (C-10), 37.0 (C-3), 38.9 (C-1), 40.6 (C-5), 45.9 (C-4), 51.0 (C-9), 52.2 (C-21), 52.9 (C-12), 56.1 (C-7), 64.2 (C-8), 68.2 (C-15), 73.1 (C-14), 173.4 (C-13), 178.3 (C-18). HRMS: Calcd for $\mathrm{C}_{21} \mathrm{H}_{32} \mathrm{O}_{6}$ : 380.21989; Found: $380.21962\left(\mathrm{M}^{+*}\right)$.

\section{Acknowledgements}

This work was supported by the Fundação de Amparo à Pesquisa do Estado de São Paulo (FAPESP). C.S. gratefully acknowledges CNPq and FAEP/UNICAMP for fellowships. We also thank Prof. R. Custódio and Mr. A. de L. Machado for assistance with the computational calculations, Prof. L.H.B. Baptistella for helpful discussions and Dr. C.H. Collins for reviewing this article.

\section{References}

1. Ikan, R.; Natural Products: A Laboratory Guide; Israel Universities: Jerusalem, 1969, p.169.

2. Dewick, P. M.; Nat. Prod. Rep. 1997, 14, 111.

3. Haslinger, E.; Hüfner, A.; Monatsh. Chem. 1995, 126, 1109; Kuzakov, E. V.; Shmidt, E. N.; Bagryanskaya, Y.; Gatilov, Y. V.; Chem. Nat. Comp. 1994, 30, 339; Abad, A.; Agullo, M.; Arno, M.; Cuñat, A. C.; Zaragoza, R. J.; J. Org. Chem. 1989, 54, 5123; Abad, A; Arno, M.; Domingo, L.R.; Zaragoza, R.J.; Tetrahedron 1985, 41, 4937; Suryawanshi, S. N.; Rani, A.; Dhami, T. S.; Bhakuni, D. S.; Synth. Commun. 1989, 19, 2927; Steindl, H.; Haslinger, E.; J. Org. Chem. 1985, 50, 3749; Koyama, H.; Okawara, H.; Kobayashi, S.; Ohno, M.; Tetrahedron Lett. 1985, 26, 2685. 
4. Koyama, H; Kaku, Y.; Ohno, M.; Tetrahedron Lett. 1987, 28, 2863; Okawara, H; Nakai, H., Ohno, M.; Tetrahedron Lett. 1982, 23, 1087.

5. Akita, H.; Oishi, T.; Chem. Pharm. Bull. 1981, 29, 1580.

6. Santos, C.; Rosso, C. R. S.; Imamura, P. M.; Synth. Commun. 1999, 29, 1903.

7. Hess, S. C., Farah, M. I. S.; Eguchi, S. V.; Imamura, P. M.; J. Braz. Chem. Soc. 2000, 11, 59.

8. Santos, C., PhD Thesis, Universidade Estadual de Campinas, Brazil, 2002.

9. M. John, K. krohu, U. Flörke, H-.J. aust, S. Draeger, B. Schulz, J. Nat. Prod. 1999, 62, 1218.

10. SPARTAN ${ }^{\circledR}$, version 1.5; Wavefunction Inc., 18041 Von Karman Ave. Suite 370, Irvine CA 92612 USA, 2000.

11. Hyperchem 6.03 professional $^{\circledast}$. Hypercube, Inc., Gainesville, USA, http://www.hyper.com/products/Registration/hyper6.03, accessed in May 2001.

12. Valverde, S.; Lopez, J. C.; Rabanal, R. M.; Escudero, J.; Tetrahedron 1986, 42, 573;

13. Presser, A.; Haslinger, E. Wels, R.; Hüfner, A.; Monatsh. Chem. 1998, 129, 921.

14. Landucci, L. L.; Holzforschung 1991, 45, 341; Smith, W. B.; Org. Magn. Reson. 1978, 11, 427.

15. Scheidegger, U; Schaffner, K.E.; Jeger, O.; Helv. Chim. Acta 1962, 45, 400 .
16. Gesson, J.P.; Jacquesy, J. C.; Renoux, B.; Tetrahedron 1989, $45,5853$.

17. Shimoma, F.; Kondo, H.; Yuuya, S.; Suzuki, T.; Hagiwara, H.; Ando, M.; J. Nat. Prod. 1998, 61, 22.

18. Santos, R. B.; Brocksom, T. J.; Brocksom, U.; Tetrahedron Lett. 1997, 38, 745.

19. Garlaschelli, L.; Vidari, G.; Gazz. Chim. Ital. 1987, 117, 251.

20. Berti, G.; Macchia, B.; Macchia, F.; Tetrahedron Lett. 1965, 6, 3421.

21. Henbest, H. B.; Smith, M.; Thomas, A.; J. Am. Chem. Soc. 1958, 3292.

22. Nwaukwa, S. O.; Keehn, P. M.; Tetrahedron Lett. 1982, 23, 35 .

23. Albright, J. D.; Goldman, L.; J. Am. Chem. Soc. 1967, 89, 2416.

24. Cheng, Y. S.; Liu, W. L.; Chen, S.; Synthesis 1980, 223.

25. Leung, W. H.; Wong, T. K.T.; Tran, J. C. H.; Yeung, L. L.; Synlett 2000, 677.

Received: February 12, 2003

Published on the web: December 9, 2003

FAPESP helped in meeting the publication costs of this article. 